\title{
The steps from sexual reproduction to apomixis
}

\author{
Xitong Fei ${ }^{1}$ Jingwei Shi ${ }^{1}$ Yulin Liu ${ }^{1}$ Jinshuang Niu ${ }^{1} \cdot$ Anzhi Wei $^{1}$ \\ Received: 14 January 2019 / Accepted: 18 February 2019 / Published online: 8 April 2019 \\ (c) The Author(s) 2019
}

\begin{abstract}
Main conclusion In this paper, an interaction model of apomixis-related genes was constructed to analyze the emergence of apomictic types. It is speculated that apomixis technology will be first implemented in gramineous plants.

Apomixis (asexual seed formation) is a phenomenon in which a plant bypasses the most fundamental aspects of sexual reproduction-meiosis and fertilization-to form a viable seed. Plants can form seeds without fertilization, and the seed genotype is consistent with the female parent. The development of apomictic technology would be revolutionary for agriculture and for food production as it would reduce costs and breeding times and also avoid many complications typical of sexual reproduction (e.g. incompatibility barriers) and of vegetative propagation (e.g. viral transfer). The application of apomictic reproductive technology has the potential to revolutionize crop breeding. This article reviews recent advances in apomixis in cytology and molecular biology. The general idea of identifying apomixis was proposed and the process of the emergence of non-fusion types was discussed. To better understand the apomixis mechanism, an apomixis regulatory model was established. At the same time, the realization of apomixis technology is proposed, which provides reference for the research and application of apomixis.
\end{abstract}

Keywords Apomixis $\cdot$ Genetic breeding $\cdot$ Apospory $\cdot$ Plant reproduction $\cdot$ Seed development $\cdot$ Embryonic development

\section{Introduction}

In angiosperms, double fertilization is the common reproductive pattern in which two sperms combine with an egg cell and a central cell. The former develops into an embryo, the embryonic form of a new plant, and the latter develops into an endosperm whose function is to support the early growth of this new plant (Lopes and Larkins 1993). During sexual reproduction, fertile pollen is essential to fertilize the central nucleus of the embryo sac and ensure viable seed production (Boldrini et al. 2006). By contrast, seed formation also occurs in apomictic plants but without fertilization. In apomictic plants, the genetic information of the offspring is consistent with the female parent, but the process of formation is different. Apomixis can be divided into three types: displospory, apospory, and adventitious embryony. Among them, displospory and apospory are derived from

Anzhi Wei

Weianzhi@126.com

1 College of Forestry, Northwest A\&F University, Yangling, Shaanxi, China unreduced embryo sacs, and adventitious embryony is derived from somatic cells (Koltunow 1993).

In agriculture, apomixis has the potential to transform plant breeding, allowing new varieties to retain valuable traits through asexual reproduction. The production of seeds without sexual union is considered the holy grail of plant biology (Hofmann 2010). Some families naturally show particularly high frequencies of apomixis, examples are: Poaceae (Sharma et al. 2014; Boldrini et al. 2006; Hojsgaard et al. 2008; Albertini et al. 2005; Niemann et al. 2012), Asteraceae (Whitton et al. 2008; Hand et al. 2015), Rosaceae (DOBEŠ et al. 2015; Burgess et al. 2014) and Melastomataceae (Mendes-Rodrigues and Oliveira 2012; Maia et al. 2016). In 1986, Richards counted known apomictic species, finding more than 300 taxa, distributed over 35 families (Richards 1986). Today, according to incomplete statistics, plants found to have apomictic reproductive ability exceed 400 genera (Grimanelli et al. 2003; Koltunow and Grossniklaus 2003).

However, the taxonomic distribution of apomictic taxa across the plant lineages is uneven, with estimations of $0.1 \%$ in angiosperms, up to $10 \%$ in ferns, and with little or no 
evidence of its existence in gymnosperms, mosses, liverworts or hornworts (Walker 1966; Lovis 1977; Asker 1992; Pichot 2001; Park 2003). Sexual reproduction is ancestral in homosporous ferns, and the transition to apomixis requires the evolution and alternation of two distinct phenomena: diplospory and apogamy. These represent the avoidance of meiotic reduction during sporogenesis (diplospory) and the spontaneous development of a sporophyte without fertilization (apogamy) (Lovis 1977). Apomictic mechanisms are historically subdivided into two categories and classified as either gametophytic or sporophytic, based on whether the embryo develops via a gametophyte (embryo sac) or directly from diploid somatic (sporophytic) cells within the ovule (Koltunow 1993; Nogler 1984). Most apomictic plants retain some potential for sexual reproduction, called facultative apomixis (Koltunow and Grossniklaus 2003). Apomixis leads to genetically identical offspring and this would allow a crop to retain complex features that are of value and also the production of seeds with superior traits, directly from the mother plant. Through these the seed production cycle would be shortened and the high cost of producing hybrid seeds would be eliminated (Bicknell and Koltunow 2004). Although apomixis is potentially important for crop breeding and has been studied extensively, the genetic regulation of apomixis remains unclear and the results obtained in studies of the apomictic mechanism are not always consistent (Galla et al. 2017). Over the last few years, reviews have focused on various aspects of apomixis including the different genetic control mechanisms. The study of apomixis from cytological and molecular biological perspectives may facilitate the application of this technology to key crops.

\section{How to determine apomixis}

To study the mechanism of apomixis, the first step is to find and identify which plants have apomictic characteristics. Plants can still produce fertile offspring after emasculation or blocking pollination, and it can be initially determined that the material studied is apomictic. In addition, the test of maintenance of maternal genotye in the offspring can be used to determine whether the progeny genes are all derived from the female parent, and the ploidy relationship between the endosperm and the somatic cells can be examined by flow cytometry to further prove that the material has apomictic characteristics. Microscopic techniques are used to observe the development of the embryo sac and to determine the source of the embryo to determine the type of apomixis. It is also possible to further determine whether the plant is obligate apomixis or facultative apomixis in combination with pollination experiments. Finally, apomixis can be identified at the molecular level, for example by looking for specific genes or markers, UPGRADE2 is highly upregulated in pollen mother cells, whereas in homologous reproduction there is no homologue in Boechera spp., which is identified as a specific transcript unique to apomixis (Mau et al. 2013). The emergence of specific sequences has made it possible to develop apomictic markers. Biomarkers provide an idea for the identification of apomictic, but it seems unrealistic to screen for universal marker genes in a wide range of species. It can be combined with other methods of identification to identify apomixis as an adjunct.

\section{Cytological study of apomixis}

There are two main forms of apomixis (Fig. 1): (1) sporophytic and (2) gametophytic. Sporophytic apomixis involves the direct formation of an embryo from a somatic cell in the ovule. In gametophytic apomixis the embryo sac is obtained via apospory and diplospory. In both cases, the unreduced egg cell develops parthenogenetically into an embryo. At the same time, endosperm development in apomictic species may be independent of fertilization (autonomous endosperm formation) or may need the fusion of the polar nuclei with a pollen nucleus (pseudogamy) (Koltunow and Grossniklaus 2003).

In facultative apomixis in sexual plants, the appearance and differentiation of archesporial cells occur at much the same time. During the development of the aposporous embryo sac, the nucellus cells close to the megaspores gradually become larger and form an aposporous initial. After two mitoses, these develop into an aposporous embryo sac. In a study of the ovule of Poncirus trifoliate, aposporous initials were not evident prior to megaspore formation but, in one ovary, an archesporial cell was observed with nearby enlarged nuclear cells-possibly representing an aposporous initial (Sharma et al. 2014).

Polyembryony is more common than might be expected in sexually reproducing species. In general, it is associated with apomixis (Mendes-Rodrigues and Oliveira 2012). The emergence of polyembryony is thought to be a result of apomixis. Polyembryony is the phenomenon of forming multiple embryos in one ovule. There are many species exhibiting polyembryonal behavior including Mangifera indica L. (Litz et al. 1982), Citrus unshiu (Nakano et al. 2012) and Clidemia hirta (L.) (Mendes-Rodrigues and Oliveira 2012). The occurrence of polyembryony is believed to be caused by apomixis and generally occurs through adventitious embryo development of nucellar cells. The existence of polyembryony in a species is usually associated with one in which there is a high probability of apomixis. Indeed, the presence of polyembryony is considered indicative of apomixis. 


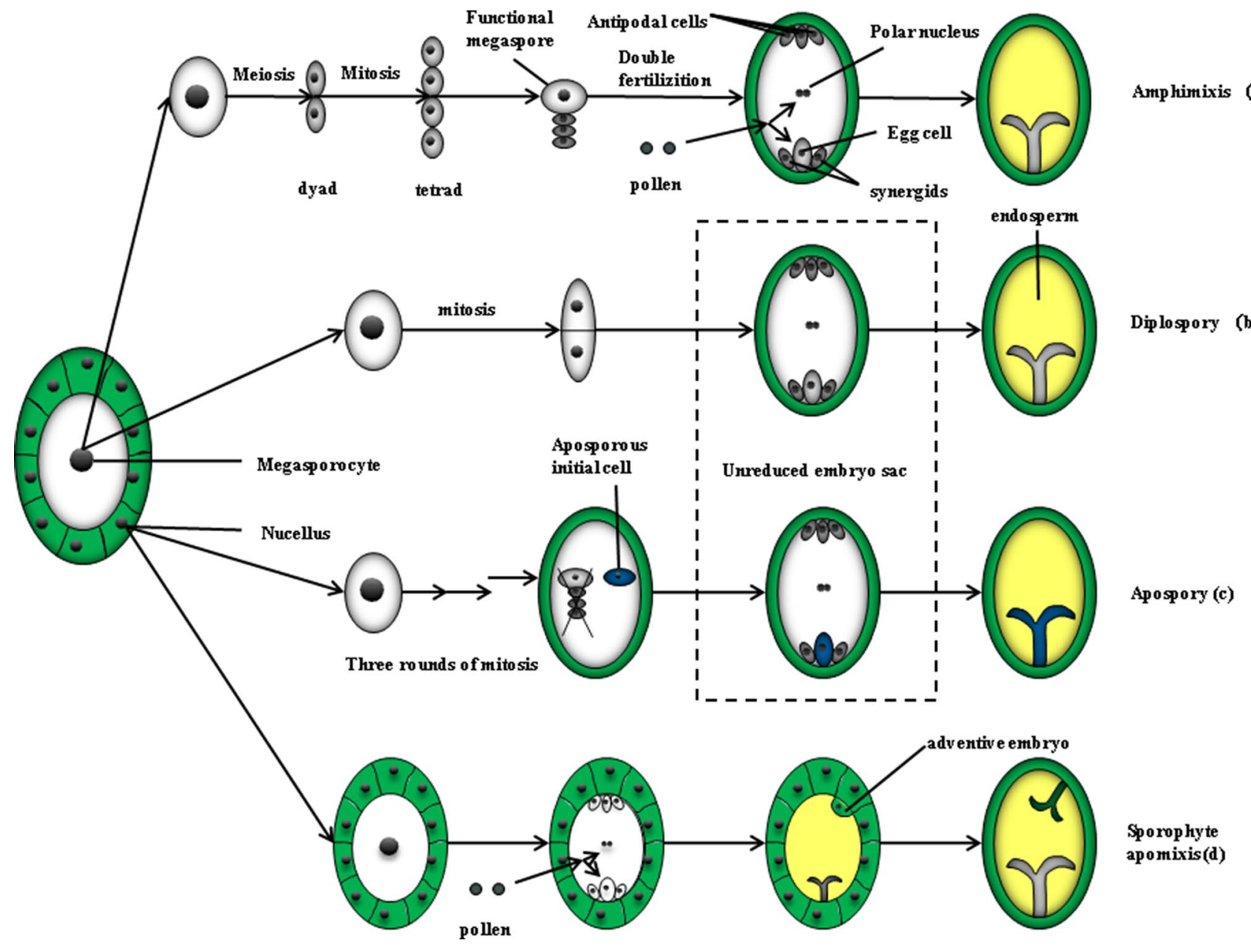

Fig. 1 Amphimictic and apomictic embryo formation. a Amphimixis, the megaspore mother cells undergo mitosis and meiosis to form an embryo sac with 8 nucleus, and then form embryos under the double fertilization; (b) Diplospory, the megaspore mother cells undergo mitosis to form unreduced embryo sac, and the apomictic initiation cells originate from the location of the megaspore mother cells and eventually develop into embryos; (c) Apospory, the aposporous ini- tial cells (AI) near the megaspore mother cells form an unreduced embryo sac undergoes three rounds of mitosis and eventually develop into embryos; (d) Sporophyte apomixis, the apomictic initiation cells are derived from ovules, which rapidly divide and invade the embryo sac, producing one or more embryos, and sporophyte apomixis can coexist with amphimixis
Some apomictic species and their biological characteristics are summarized in Table 1, including Poaceae, Asteraceae, Rutaceae, Rosaceae, Melastomeae, Ranunculaceae and the like. According to the information available (Table 1), the majority of apomictic plant species are polyploid. Polyploidy is commonly accompanied by changes in the reproductive system such as the breakdown of selfincompatibility (Barrett 1988). This leads to instability of the reproductive system and this, in turn, to the emergence of new types of reproduction. The generation of apomictic characteristics is closely related to the environment in which plants live over long periods. In addition, facultative apomixis plants retain sexual reproduction patterns but will reproduce asexually in the absence of a male gamete or sexually after fertilization. These two modes can exist together and are independent (Vielle-Calzada et al. 1996). However, sexual reproduction and apomixis have been shown to have different regulatory pathways in cell cycle control, hormonal pathways, epigenetic and transcriptional regulation. For example, spermidine metabolism is involved in somatic embryogenesis in various plants and is a specific signal transduction pathway for the apomictic germline (Schmidt et al. 2014).

In the study of apomictic species, some still maintain an ability for gametogenesis, the facultative apomicts. As a biological trait, facultative apomixis has evolved over a very long period. It is a stable trait that allows rapid colonization of large areas. This situation provides genetic researchers with abundant plant material and with sufficient time for testing (Hojsgaard et al. 2014). The genus Boechera is closely related 


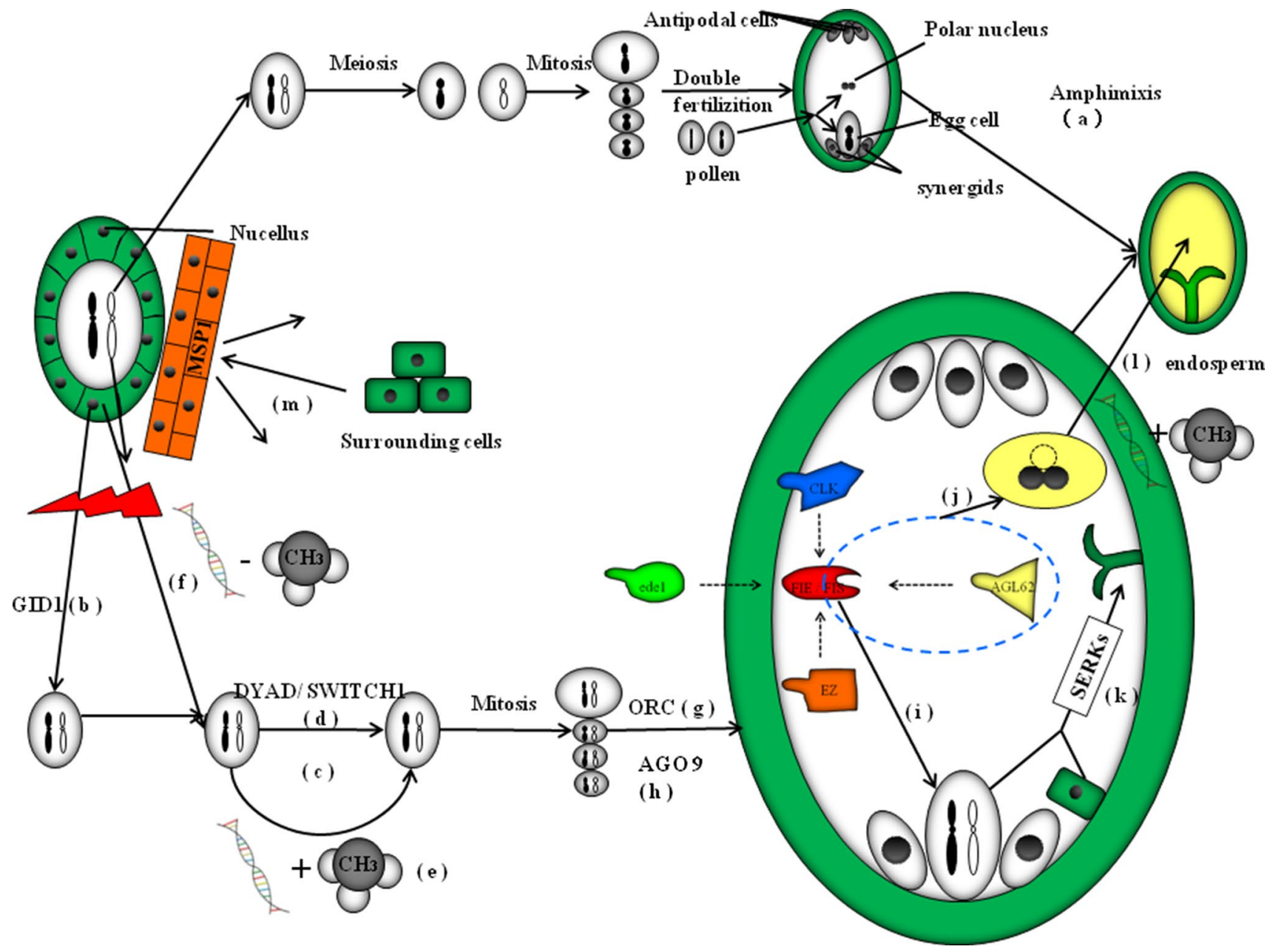

Fig. 2 Model of apomixis. a Amphimixis. bGIDl overexpression triggers differentiation of MMC-like cells (Ferreira et al. 2018). c Mitosis or apomeiosis. $\mathbf{d} D Y A D /$ SWITCH1 gene is considered necessary in the process of female gamete meiosis. Its absence can cause meiosis of the megasporocytes to fail (Agashe et al. 2002; Boateng et al. 2008). e DNA methylation is often associated with apomeiosis, and methylation is always present during subsequent reproduction (Podio et al. 2014; Selva et al. 2017). f Demethylation can significantly inhibit the occurrence of parthenogenesis (Podio et al. 2014). $\mathbf{g O R C}$ is a multiprotein complex which controls DNA replication and cell differentiation in eukaryotes (Siena et al. 2016). hARGONAUTE 9 (AGO9) controls female gamete formation by limiting the specification of gametophyte precursors in a non-cell-autonomous manner (Olmedo-Monfil et al. 2010). iFIE genes, co-regulated with $C L K$, ede1, EZ and other related genes, can promote the independent development of egg cells into embryos without fertilization (Liu et al. 2012b, 2012a). j AGL62 binds to FIS to form a complex and mediates the cellulogenesis of the endosperm (Hehenberger et al. 2012). $\mathbf{k}$ SERKs family genes have been shown to be the switches of somatic cell differentiation, playing an active role in apomimetic reproduction (Albertini et al. 2005; Podio et al. 2014). I Modification of DNA methylation is one mechanism through which imprinting may be altered to allow endosperm development in apomicts (Spielman et al. 2003). m Surrounding cells can be blocked out of the nucellar cells by $M S P 1$, a gene that controls early sporogenic development (Nonomura 2003) to Arabidopsis, contains apomictic and sexual reproduction species, and has low ploidy levels. It is an ideal material for studying apomixis (Aliyu et al. 2010). Therefore, the extensive molecular genetic resources that exist for $A$. thaliana-including the complete genome sequence and wide range of reproductive mutants - can be used to identify and isolate genes 
Table 1 Apomictic species and related information

\begin{tabular}{|c|c|c|c|c|}
\hline Family & Species & Ploidy & Type of apomixis & References \\
\hline \multirow[t]{11}{*}{ Poaceae } & Cenchrus ciliaris & Tetraploid $(2 n=4 x=36)$ & Facultative apomixis & Dwivedi et al. (2007) \\
\hline & Paspalum minus & $\begin{array}{l}\text { Diploid, tetraploid, and penta- } \\
\text { ploid }(2 x, 4 \times \text { and } 5 x, n=10)\end{array}$ & Apomixis & Bonilla and Quarin (1997) \\
\hline & Poa pratensis & Diploid $(2 n=42)$ & Facultative apomixis & Niemann et al. (2012) \\
\hline & Paspalum notatum & Tetraploid $(2 n=4 x=40)$ & Obligate apomixis & Podio et al. (2014) \\
\hline & Paspalum Anachyris & Tetraploid $(2 n=4 x=40)$ & Apomixis & Hojsgaard et al. (2008) \\
\hline & Pennisetum glaucum & Diploid $(2 n=2 x=14)$ & Sexual or apomixis & Sahu et al. (2012) \\
\hline & Brachiaria decumbens & Tetraploid $2 n=4 x=36$ & Sexual or apomixis & Worthington et al. (2016) \\
\hline & Brachiaria humidicola & $\begin{array}{l}\text { Hexaploid } 2 n=6 x=54 / \text { hepta- } \\
\text { ploid }(2 n=7 x=42)\end{array}$ & Apomixis & Boldrini et al. (2006) \\
\hline & Potentilla puberula & Tetraploid $(2 n=4 x=28)$ & Preferentially apomictic & Dobes et al. $(2013,2018)$ \\
\hline & Eragrostis curvula & Polyploid ( $4 \times$ to $7 x, n=10$ ) & Apomixis & Selva et al. (2012) \\
\hline & Panicum maximum & Tetraploid $2 n=4 x=32$ & Apomixis & $\begin{array}{l}\text { Lu and Vasil (1981); Rad- } \\
\text { hakrishna et al. (2018) }\end{array}$ \\
\hline \multirow[t]{5}{*}{ Asteraceae } & Hieracium praealtum & $\begin{array}{l}\text { Aneuploid }(3 x+4=2 n=31) \\
\text { tetraploid }(3 x=2 n=27)\end{array}$ & Facultative apomixis & Okada et al. (2013) \\
\hline & Hieracium pilosella & Tetraploid $(2 n=4 x=36)$ & Specialist apomixis & Guerin et al. (2000) \\
\hline & Erigeron аппииs & $\begin{array}{l}\text { Triploid (apomixis) or diploid } \\
\text { (sexual) } 2 n=3 x=27 \\
2 n=2 x=18\end{array}$ & Facultative apomixis & Noyes and Rieseberg (2000) \\
\hline & Crepis barbigera & Polyploid $(\sim 7-8 \mathrm{x})$ & Apomixis & $\begin{array}{l}\text { Whitton et al. (2008); Hersh } \\
\text { et al. (2016) }\end{array}$ \\
\hline & Taraxacum officinale & $\begin{array}{l}\text { Triploid (apomixis) } \\
\qquad \begin{array}{l}2 n=3 x=24, \text { diploid sexuals } \\
(2 n=2 x=16)\end{array}\end{array}$ & Facultative apomixis & Dijk and Bakx-Schotman (2004) \\
\hline \multirow[t]{2}{*}{ Rutaceae } & Poncirus trifoliata & Tetraploid $(2 n=4 x=36)$ & Facultative apomixis & Hussain et al. (2011) \\
\hline & Citrus reticulata & Diploid $(2 n=2 x=18)$ & Facultative apomixis & Wang et al. (2017) \\
\hline \multirow[t]{4}{*}{ Rosaceae } & Amelanchier & Triploid $(2 n=3 x=51)$ & Apomixis & Burgess et al. (2014) \\
\hline & Crataegus suksdorfii & $\begin{array}{l}2 n=2 x, 3 \times \text { and } 4 \times 2 x \\
\text { self-incompatible diploid } \\
\text { sexual detailss } 3 \times \text { apomicts } \\
4 \times \text { self-compatible tetraploid } \\
\text { pseudogamous apomicts }\end{array}$ & - & Lo et al. (2009) \\
\hline & Malus hupehensis & Triploid ( $2 n=3 x=51$ ) & Facultative apomixis & Liu et al. (2014) \\
\hline & Potentilla indica & Tetraploid (-) & Apomixis & DOBEŠ. et al. (2015) \\
\hline Melastomeae & Tibouchina hatschbachii & $-n=9$ & Apomixis & Maia et al. (2016) \\
\hline \multirow[t]{2}{*}{ Ranunculaceae } & $\begin{array}{l}\text { Anemopaegma acutifolium, } A . \\
\text { arvense and } A . \text { glaucum }\end{array}$ & Tetraploid $(2 n=4 x=80)$ & Facultative apomixis & (Sampaio. et al. 2013) \\
\hline & Ranunculus auricomus & $2-4 x$ & Apomixis & Nogler (1984) \\
\hline Dryopteridaceae & Crepis barbigera & Tetraploid $(2 n=4 x=96)$ & Apomixis & Hersh et al. (2016) \\
\hline Chenopodiaceae & Beta vulgaris & Tetraploid $(2 n=3 x=27)$ & Facultative apomixis & $\begin{array}{l}\text { Szkutnik (2010; Dedong et al. } \\
\text { (1999) }\end{array}$ \\
\hline Brassicaceae & $\begin{array}{l}\text { Arabis holboellii (Boechera } \\
\text { holboellii) }\end{array}$ & Triploid $(2 n=3 x=21)$ & Facultative apomixis & $\begin{array}{l}\text { Naumova et al. (2001); Aliyu } \\
\text { et al. (2010) }\end{array}$ \\
\hline Aspleniaceae & Asplenium monanthes & $\begin{array}{l}\text { Triploid }(n=2 n=108 \text { and } \\
2 n=144)\end{array}$ & Apomixis & Dyer et al. (2012) \\
\hline Guttiferae & Hypericum perforatum & Tetraploid $2 n=4 x=32$ & Facultative apomixis & Barcaccia et al. (2006) \\
\hline Juglandaceae & Carya cathayensis & Diploid $2 n=2 x=32$ & Apomixis & Zhang et al. (2012) \\
\hline Myrtaceae & Psidium cattleyanum & $\begin{array}{l}\text { Polyploid, } n=11,2 n=44, \\
2 n=55,2 n=66,2 n=77 \\
2 n=82 \text { and } 2 n=88\end{array}$ & Facultative apomixis & Souza-Pérez and Speroni (2017) \\
\hline Euphorbiaceae & Manihot esculenta & $2 n=38$ & Facultative apomixis & Nassar and Collevati (2008) \\
\hline Cucurbitaceae & Bryonia alba & - & Apomixis & Novak and RN Mack (1995) \\
\hline
\end{tabular}


Table 1 (continued)

\begin{tabular}{lllll}
\hline Family & Species & Ploidy & Type of apomixis & References \\
\hline Ulvaceae & Ulva prolifera & - & Apomixis & Ogawa et al. (2015) \\
Gigartinaceae & Mastocarpus stellatus & - & Apomixis & Li et al. (2016) \\
Pteridaceae & Cheilanthes yavapensis & Tetraploid $(2 n=4 x=120)$ & Apomixis & Grusz et al. (2009); Windham \\
& & & & $(1993)$ \\
\hline
\end{tabular}

involved in apomictic processes in Boechera holboellii (Naumova et al. 2001; Sharbel et al. 2009). Moreover, Boechera holboellii genome-wide data has been published, and its research on apomictic-related genes has made some progress, laying a foundation for the study of apomixis (Kliver et al. 2018).

\section{Molecular study of apomixis}

There are relatively few studies of the molecular regulation of apomixis but some achievements have been made, and these lay a solid foundation for further studies (Table 2). DNA methylation is often associated with apomeiosis, and methylation is always present during subsequent reproduction. The DNA methylation pathway plays an important role in the development of gametophytes, and there are differences in apomictic and sexual reproduction. It has been found that the genes $d m t 102$ and $d m t 103$ in ovules are expressed mainly in restricted domains in and around germ cells (Fig. 2e) (Garcia-Aguilar et al. 2010). This suggests DNA methylation pathways are critical for maize gametophyte development during reproduction and may play key roles in apomictic and sexual reproduction. To study the effects of DNA demethylation on reproduction patterns in Paspalum simplex, the progeny of apomictic plants treated with the demethylation agent 5 '-azacytidine have been analyzed (Fig. 2f). The results indicate the apomictic genus Parthenogenetic inhibitory factor may be inactivated by DNA methylation (Podio et al. 2014). Moreover, modification of DNA methylation is one mechanism through which imprinting may be altered to allow endosperm development in apomicts (Fig. 21) (Spielman et al. 2003).

Polycomb-group $(\mathrm{PcG})$ has been shown in many studies to be one of the regulatory cores in apomixis. Polycomb-group (PcG) mechanisms are based on two principal types of multiprotein complex, polycomb repressive complex 1 (PRC1) and polycomb repressive complex 2 (PRC2) (Schwartz and Pirrotta 2008). The PRC2 complex is concentrated in Drosophila, mammals and flowering plants. In Drosophila, the PRC2 complex consists of three PcG proteins - an additional sex comb (Esc), an inhibitor of Zeste $12(\mathrm{Su}(\mathrm{Z}) 12)$ and an enhancer of Zeste [E(z)] and additional core proteins such as $\mathrm{p} 55$. Esc and $\mathrm{p} 55$ are WD-40 proteins; $\mathrm{Su}(\mathrm{z}) 12$ is a $\mathrm{C} 2 \mathrm{H} 2$ zinc finger; E(z) is a SET-domain protein that uses methylating histone $\mathrm{H} 3$ lysine 27 (H3K27) to silence target gene expression (Schwartz and Pirrotta 2008). The disruption of PRC2 gene expression may result in abnormal seed development in Arabidopsis (Hehenberger et al. 2012) and rice (Folsom et al. 2014). Fertilization-independent seed (FIS) and fertilization-independent endosperm (FIE) are important members of the polycomb group. FIS genes play important regulatory roles in the growth and development of plants, especially in the formation of seeds in sexual reproduction. The expression level of this gene is significantly different between sexual and apomictic apple species. From this, it can be inferred that this gene may be involved in the regulation of apomictic apple species (Liu et al. 2012b). In the mutant of Arabidopsis thaliana FIS gene, the degeneration of the embryo and the excessive development of endosperm can be observed (Fig. 2i) (Kiyosu. et al. 1999). In tomato, FIE silencing results in the formation of abnormal phenotypes during reproductive development. Examples include, increased numbers of sepals and petals, a fused ovule and pistil and parthenocarpic fruit formation (Liu et al. 2012a). In addition, the genes of the polycomb family have been shown to autonomous development of the endosperm in the absence of fertilization is repressed (Fig. 2i) (Kiyosu et al. 1999). AGL62 binds to FIS to form a complex and mediates the 65 cellulogenesis of the endosperm (Fig. 2j) (Hehenberger et al. 2012).

$A G O 9$ can induce the ovule to produce multiple archespores, this provides a primitive source of cells for the formation of multiple embryos (Fig. 2h) (Olmedo-Monfil et al. 2010). Apomeiosis occurs in the mutant Arabidopsis thaliana gene DYAD/ SWITCHI (SWI1), indicating that the DYAD/ SWITCH1 gene can regulate meiosis (Fig. 2d). Most fertile ovules in $D Y A D$ plants form triploid seeds, which are produced by fertilization of unreduced female gamete by a haploid male gamete, which in some cases lead to infertility in offspring. However, the mutation of a single gene leads to functional apomeiosis of the sexual reproductive species, providing a reference for studies leading to apomictic mechanisms (Ravi et al. 2008). In addition, ORC is a multiprotein complex which controls DNA replication and cell differentiation during apomixis (Fig. 2g) (Siena et al. 2016). Furthermore, GIDI may participate in the differentiation of a single megaspore mother cell in ovule development and 


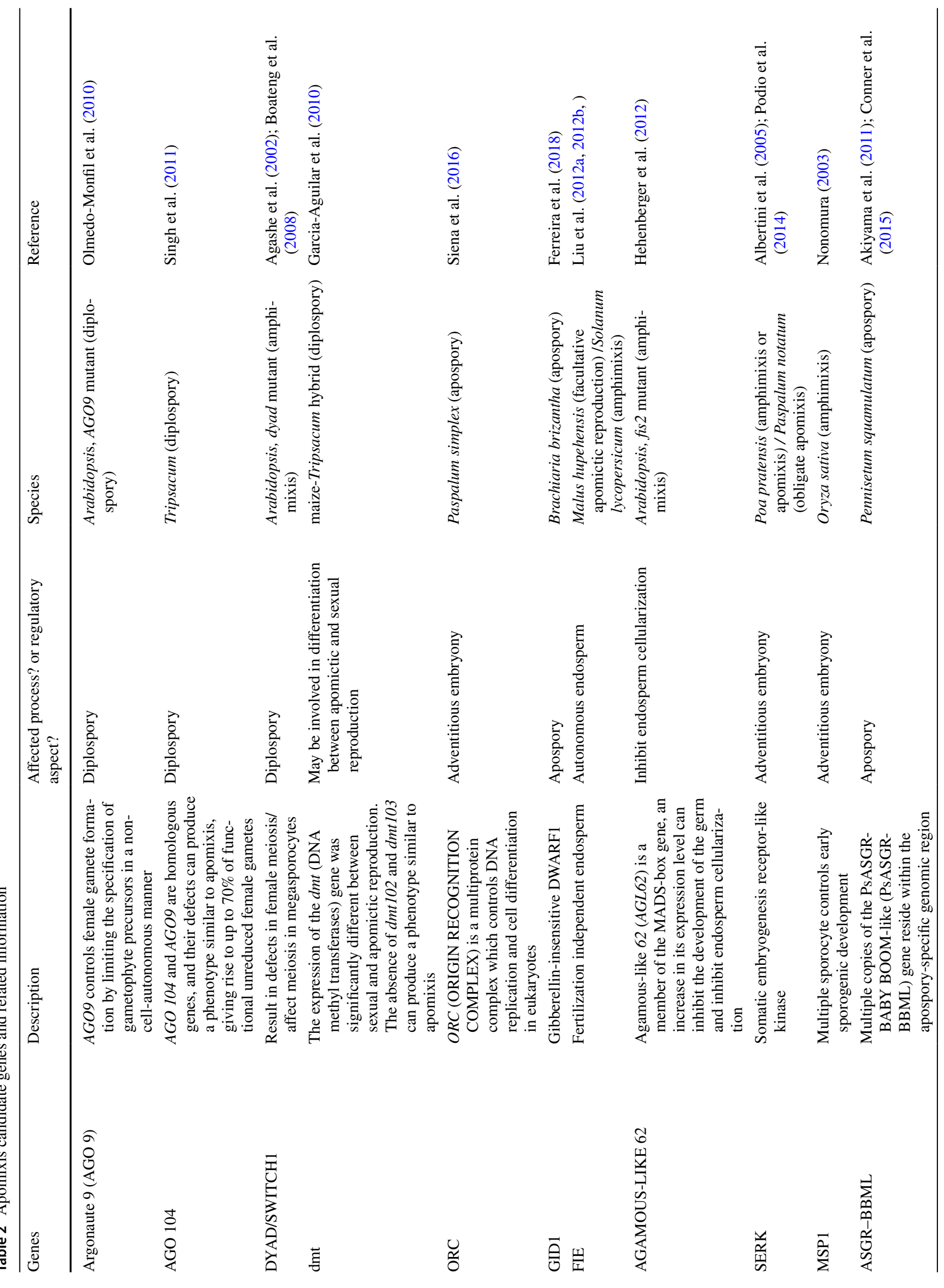




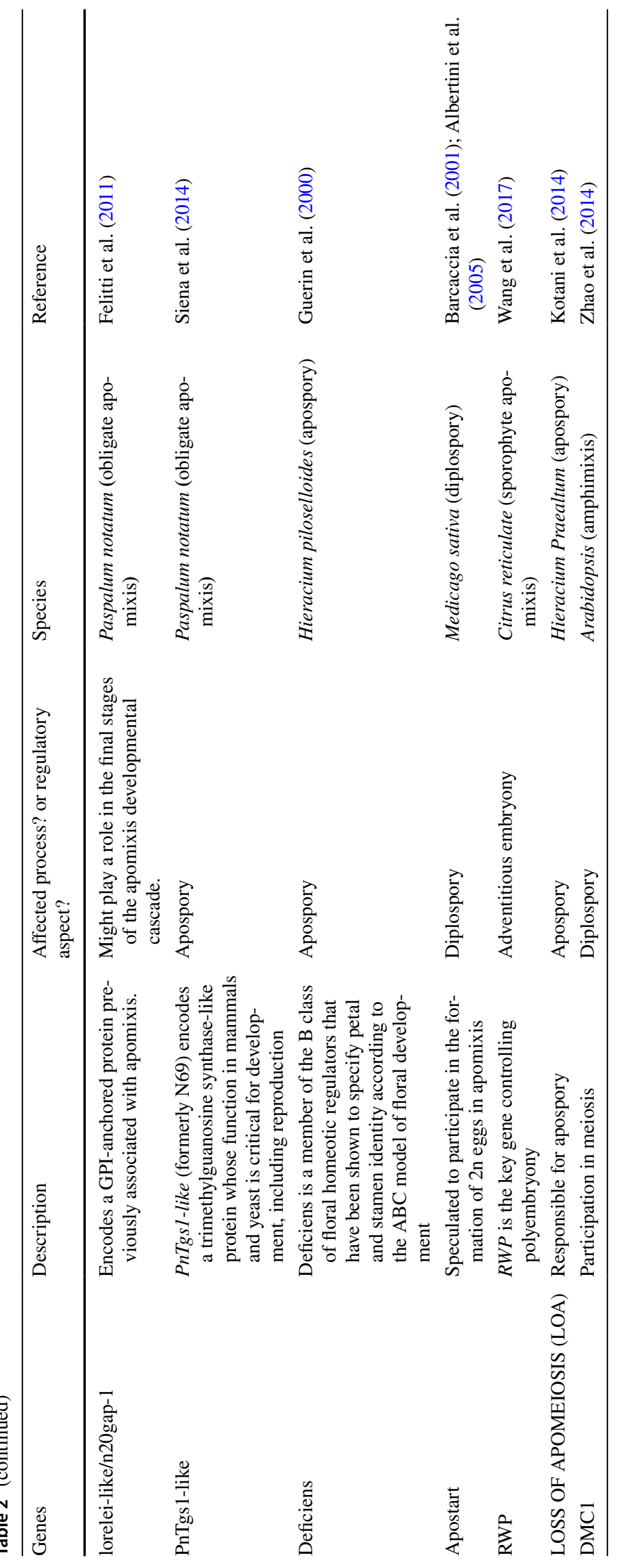


provide valuable information on the role of GIDl in sexual and apomictic reproduction (Fig. 2b) (Ferreira et al. 2018). In the nucellar cells of apomictic genotypes, the Poa pratensis SERK gene plays a key role in embryo sac development and it may also transfer signaling gene products to compartments other than their typical ones (Albertini et al. 2005). The Paspalum notatum SERK2 gene is expressed in the nucellar cells of the apomictic genotype during meiosis but, in the sexual genotype, it is expressed only in the megaspore mother cell (Fig. 2k) (Podio. et al. 2014). The MSPl gene encodes Leu-rich repeat receptors, such as protein kinase. The function of this gene in rice is to suppress sporogenesis in the surrounding cells and to inhibit anther wall formation. This could be indicated by the MSPl expression pattern and the phenotype of loss-of-function mutants. In contrast, the mutation of $M S P 1$ could give rise to an enormous number of male and female sporocytes, lead to disorders of the anther wall layer formation and result in the disappearance of the tapetum layer (Fig. 2m) (Nonomura 2003).

In addition to the above genes, there are many other genes involved in apomixis. SuperSAGE was used to identify micro-dissected ovules differentially expressing mRNA tags between two diploids (Boechera stricta and B. holboellii) and two diploid apomicts (Boechera divaricarpa). As a result, more than 4000 differentially expressed mRNA tags were screened. During the different developmental stages, 543 alleles were further expressed between sexual and apomeiotic ovules and 69 holboellii specific alleles were significantly upregulated in the apomeiotic ovule. The above evidences support the hypothesis of deregulation of the sexual pathway (Sharbel et al. 2009). Molecular characterization of N69 cDNA indicates that it is homologous to trimethylguanosine synthase/PRIP-interacting proteins in yeasts and mammals. These proteins can act as ERK2controlled transcriptional coactivators, sn(o)RNA mediators and telomerase RNA cap trimethylation. They can also play important developmental roles in mammals and yeasts. Consequently, the N69-extended sequence has been renamed PnTgsl-like. Transcription of PnTgsl-like in reproductive development is more abundant in floral organs of sexual genotypes than in apomicts. Such a difference is not found in nutritional tissues. Transcription levels are negatively correlated between reproductive tissues of several genotypes and facultative apomixes (Siena et al. 2014). Felitti et al reported that $n 20$ gap-1, a lorelei-like gene, encodes a GPI-anchored protein previously related to apomixis in Paspalum notatum (Felitti et al. 2011).

Moreover, small RNA also plays a regulatory role in this process. ARGONAUTE 9-dependent sRNA silencing plays a key role in cell fate in Arabidopsis ovules, whereas epigenetic reprogramming in associated cells is essential for sRNA-dependent silencing in plant gametes (OlmedoMonfil et al. 2010). In the process of sexual reproduction, hormones are also important control factors involved in the differentiation of fertilized eggs and in mitosis. Some genes related to cytokinin, auxin and brassinoin are significantly upregulated during aposporous apomixis (Galla et al. 2017).

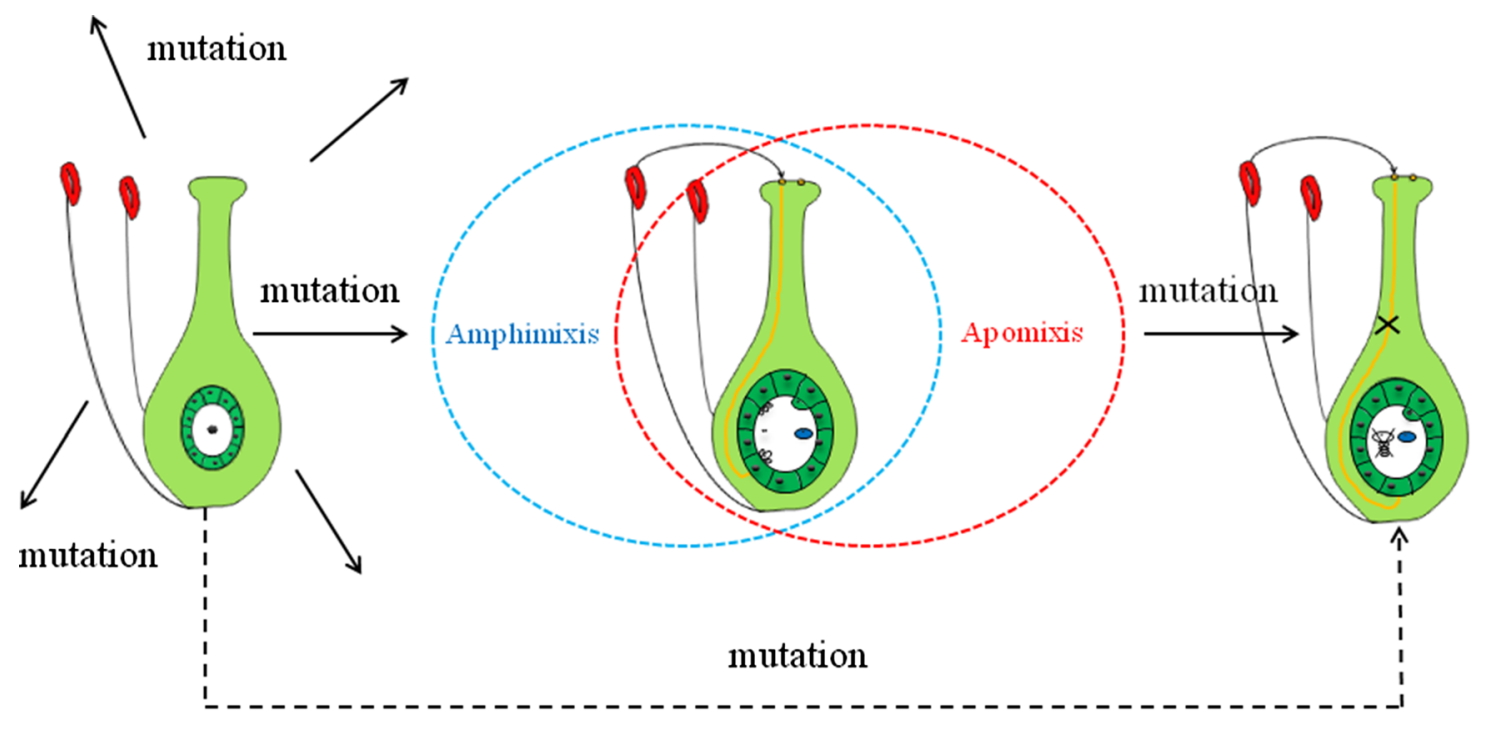

Amphimixis (a)

Facultative apomixis (b)

Obligate apomixis (c)

Fig. 3 The emergence of apomictic types. a Amphimixis (b) Facultative apomixis and (c) Obligate apomixis 
This shows plant hormones play important roles in apomictic reproduction. At the same time, the role of plant hormones in promoting the differentiation of adventitious buds has been elucidated through tissue culture techniques. Under the stimulation of exogenous steroid hormones (estrone, androsterone, progesterone and epibrassinolide), Arabidopsis thaliana can complete the development of endosperm without fertilization (Rojek et al. 2015). So it can be inferred that hormones also play important roles in the apomixis.

\section{Speculation on the emergence of apomixis}

Under the well-known double fertilization model, a number of new cases have emerged through mutation and natural selection. Many types of mutation result in plants being unable to produce fertile offspring or being unable to adapt to the environment and thus being eliminated (Fig. 3a). Some of these plant mutations produce apomixis, the macrospore mother cell degenerates and is induced to form an aposporous initial cell or adventitious embryo (Fig. 3b). The former forms an eight-cell embryo through mitosis and the latter develops into an indefinite embryo. Plants exhibit apomixis while retaining sexual reproduction, which is facultative apomixis (Fig. 3b). Obligate apomixis mutations may result in loss of sexual reproduction and obligate apomixis (Fig. 3c). Sexual reproduction direct mutations that produce obligate apomixis may require large numbers of simultaneous gene mutations, and this probability is extremely low (Fig. 3).

Meiosis is a complex process controlled by many factors. The completion of gene delivery is also an important physiological process of gametogenesis. Abnormalities in any meiotic step caused by environmental or genetic factors may affect gamete fertility. For more serious abnormalities, complete infertility can be expected (Boldrini et al. 2006).

In the past, apomixis and sexual reproduction were seen as two separate processes (Ernst 1918). It has subsequently been shown that mutagenesis can induce sexual plants to produce results similar to apomictic traits. This further supports the hypothesis that apomictic and sexual growth may share common elements (Fig. 3b) (Tucker 2003). Disruption of the developmental pathways of seed formation is hypothesized as the cause of apomixis in plants. Both hybridization and polyploidy are mechanisms that cause disruption and are typical of asexual plants (Sharbel et al. 2009). In some respects, it can be inferred that apomixis is a process that bypasses sexual reproduction to form seeds. Apomixis is also realized on the basis of part of the original sexual reproduction. Therefore, apomixis is not an isolated process. To understand its mechanism clearly it is necessary to study it in combination with sexual reproduction.
Although evolution from sexual reproduction to apomixis is relatively rare in eukaryotes, it seems to be an important evolutionary process in plants (Asker and Jerling 1992). Facultative apomixis with both amphimictic and apomictic systems, in the absence of fertilization, can produce offspring. In addition, amphimixis can occur in appropriate environments so ensuring richness in gene communication and thus improving the adaptability of offspring (Fig. 3c). Therefore, facultative apomixis can help plants adapt to complex environments and hence increase the survival rate of the offspring.

\section{Discussion}

\section{Steps towards engineering of apomixis}

Based on what we known about apomixis, we infer that implementation of apomixis must involve the following:

1. Inhibition of meiosis in the megaspore mother cells. This is needed to retain their entire genetic characteristics and to regulate their direct development into embryos. Inhibition would allow study of the mitotic pathway of megaspore mother cell development without fertilization and enable identification of the key regulatory factors of meiosis in the megaspore mother cell population. The relevant genes and enzymes are activated to induce the formation of embryos from the megaspore mother cells.

2. Induction of mitosis and the differentiation of nucellar cells, which develop directly into embryos. Nucellar cells are an important source of adventitious embryos. Induction of adventitious embryos has become an important element of apomixis technology. Multiple embryos can be developed by induction of embryo formation by nucellar cells. The number of adventitious embryos must be controlled as the formation of too many embryos can lead to weak seedlings, which do not develop into healthy plants. Therefore, genes controlling these qualitative and quantitative traits are required to ensure the effective implementation of apomictic technology.

3. Macrospore mother cells are induced to develop into diplospores by regulating the appropriate genes, so as to bypass pollination and to initiate the direct development of embryos having the same genetic makeup as the mother.

From the data collected so far, we find many species show some apomictic characteristics. While these offer a wealth of material for research, very little effort has yet been focused on elucidating the mechanism of apomixis. The overall control network has yet to be established and only this can elucidate the machinery of apomixis from the functional research of some candidate genes. Unequivocal confirmation of apomixis and the elucidation of its mechanism requires the simultaneous examination of both genetic and cytological evidence. Cytological observation should be used first to identify the 
key period(s) of embryonic development and then multi-omics technology could be used to identify a set of candidate genes. Next, model plant functional verification could be used on the gene candidates to understand apomictic gene function, the candidate genes being verified, one by one, to unravel the regulation network of the apomictic mechanism.

\section{Prediction}

Apomixis usually occurs in wild species and the ultimate goal of genetic research in apomixis has been to transfer apomixes to their crop relatives (Khan et al. 2015). So far, hundreds of apomictic plants have been found, these provide abundant material for the study of related mechanisms. The Gramineae is one of the most economically important families and contains a large number of key crops. Although apomixis is not found in any of the major graminaceous arable plants there are nevertheless large numbers of apomictic species in this family. These species offer good experimental material for use in the realization of apomixis in cereal crop plants. It is predicted that gramineous crops such as wheat and rice may become the first to achieve apomixis. In the gramineae, many species with apomixis have been found. These include: Cenchrus ciliaris, Paspalum minus, Poa pratensis, Paspalum Anachyris, Pennisetum glaucum, Brachiaria decumbens, Brachiaria humidicola, Potentilla puberula, Eragrostis curvula, Panicum maximum. Especially notable is Poa pratensis, which belongs to Poa subfamily and is closely related to barley and wheat of the same subfamily. It is also characterized by facultative apomixis and so is good material for studying this biological property.

A main component of any study of apomixis must be to better understand the differences between amphimictic and apomictic species from both physiological and also molecular perspectives. Species characterized by facultative

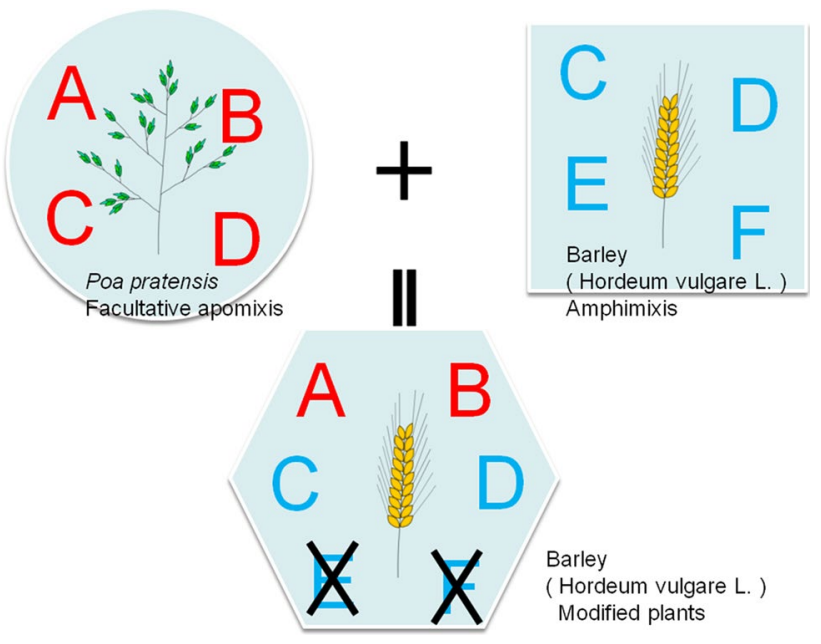

Fig. 4 The realization of apomixis apomixis are ideal experimental materials. Species exhibiting facultative apomixis can be used as research material for pollination and for non-pollination treatment. The key period of embryo formation can be determined through cytological observation. Poa pratensis (Poaceae) has the characteristics of facultative apomixis, so further study of its apomictic mechanism would likely be worthwhile. Then, the ovules will be stripped off and the ovules of the two materials analyzed in multi-omics, so the candidate genes can be approximately identified. Using a model plant for genetic validation, we will eventually confirm the key genes subsequently. The technology will be achieved through gene knockout, gene modification, overexpression and so on. At the same time, metabolomics and small RNA were studied to better understand the mechanism of apomixis. Many factors involved in the regulation of apomixis were obtained (Fig. 4). A, B, C, $\mathrm{D}, \mathrm{E}$, and $\mathrm{F}$ represent factors that participate in or that affect apomixis. They represent certain genes, active substances, functional proteins, small RNA, and transcription factors. When the influencing factors of apomictic reproduction of Poa pratensis are understood, differences and comparisons with related species, such as barley or wheat, can be made to transfer the missing factors and to inhibit the redundant factors, so as to achieve the construction of apomictic reproductive system in barley (Fig. 4c). Using this apomictic model we should be able to speed the development more efficient graminaceous crops and to reduce breeding costs.

\section{Experimental exploration of apomixis}

At this stage, however, no major seed crop species are apomictic and attempts to introduce the apomictic trait into crop plants from their apomictic relatives via conventional breeding schemes have been largely unsuccessful (Barcaccia and Albertini 2013). Nevertheless, to promote the application of related technologies, researchers have undertaken many studies on apomixis. Mutations in three genes SPO11-1, $R E C 8$ and $O S D 1$ is the best combination of meiotic modification into mitosis in Arabidopsis. At the same time, these three combinations of mutations can effectively convert meiosis into mitosis, thereby producing male and female clonal diploid gametes in rice (Mieulet et al. 2016).

Apomixis has been induced in cassava (cultivar SC5) by treating female flower buds with $1,1.5$ or $2 \%(\mathrm{v} / \mathrm{v})$ dimethyl sulfoxide (DMSO). The results show the 1.5\% DMSO treatment was most effective for inducing apomictic seed formation with the highest percentage of fruit set and the formation of true apomictic seeds (Chen et al. 2018). This study indicates there is an effective technology available for inducing apomixis. Attempts to transfer the apomictic trait to crops from wild relative species have so far resulted in partially fertile, cytogenetically unstable and agronomically unsuitable lines (Podio et al. 2014). In the past few 
years, using differential display and RNA-seq approaches, a large number of candidate genes have been identified that are involved in the reproductive organs of sexual plants and their apomictic counterparts. Laspina et al. performed a gene expression differential analysis on the immature inflorescences of Paspalum notatum and apomictic tetraploid genotypes, and finally identified 65 candidate unigenes. A series of sequences related to central cellular processes were subsequently identified by functional classification (Laspina et al. 2008). These efforts provide valuable information for revealing the mechanisms of apomixis. Furthermore, the study of apomixis can also explore endosperm development processes of apomictic species (Ogawa et al. 2013). This will also offer new opportunities for improving the breeding of species in which the endosperm is the main part of the crop. In sexual species, the endosperm typically requires a ratio of two maternal genomes to one paternal genome for normal development but this ratio is often altered in the apomicts. In the course of apomictic reproduction, all the genetic material of the endosperm comes from the mother, hence it is inferred the genotype of the endosperm is fully consistent with that of the mother.

The realization of apomixis technology has greatly promoted the development of agriculture and will bring huge innovations to agriculture, but there are still potential challenges in application. At present, genetic modification of related species has achieved good results, but there are still huge obstacles to genetic modification of distant species. The transformation of distant species is based on an in-depth understanding of the mechanism of apomixis, and the current mechanism of apomixis is still vague, so there is still a long way to go to achieve full application of apomixis.

\section{Conclusions}

If apomixis can be engineered into sexual crops in a controlled manner, its future impact on agricultural systems has the potential to be both widespread and profound. Apomixis will allow clonal seed production and this will enable seed quality to be raised and seed production costs lowered. This in turn will lower the input costs of fruit and vegetable production while also raising yields and making them more consistent (Barcaccia and Albertini 2013). It is generally agreed the introduction of apomixis to agronomically important crops will revolutionize agriculture (Pupilli and Barcaccia 2012). A better understanding of the inheritance patterns for apomixis is fundamental for facilitating the identification of candidate genes, which in turn is essential for engineering apomixis into sexual crops (Pupilli and Barcaccia 2012).

In general, apomixis is not conducive to fitness in evolution as it does not foster the propagation of new genes in a population and as it generally serves only to reduce genetic diversity. Many apomictic species retain some ability to reproduce sexually. Here, their apomictic trait enables them to thrive in environments where pollination is impossible but then, when conditions allow, they are also able to resume sexual reproduction. Hence, apomixis offers a species an enhanced ability to adapt to and survive in difficult environments. This characteristic can thus be viewed as a 'refuge' behavior which is a potentially advantageous evolutionary adaptation. In addition, it was found in the data collected that most apomictic plants are polyploid (Table 1). It may provide more opportunities for variation in plants. At the same time, multiple genetic material can attenuate adverse mutations, resulting in a higher proportion of apomixis.

At the core of the study of apomixis is to gain an understanding of the mechanism of embryo formation. The discovery of genes that are specifically or differentially expressed during embryogenesis and embryo sac formation has become key to the study of apomixis. Mastering this will greatly facilitate the realization of apomixis. Based on current research, technical level and the concerted efforts of many researchers, the establishment of apomictic technology systems is expected to be realized this century.

Author contribution statement A W conceived the project. $\mathrm{X} F$ carried out the conception of the article and the literature sorting. X F wrote the paper. All authors discussed the results and commented on the manuscript.

Acknowledgements We are grateful to Yao Ma for helpful discussion and comments on the manuscript.

Conflict of interest The authors declare no conflict of interest.

OpenAccess This article is distributed under the terms of the Creative Commons Attribution 4.0 International License (http://creativeco mmons.org/licenses/by/4.0/), which permits unrestricted use, distribution, and reproduction in any medium, provided you give appropriate credit to the original author(s) and the source, provide a link to the Creative Commons license, and indicate if changes were made.

\section{References}

Agashe B, Prasad CK, Siddiqi I (2002) Identification and analysis of DYAD_ a gene required for meiotic chromosome organisation and female meiotic progression in Arabidopsis. Development 129:3935-3943

Akiyama Y, Goel S, Conner JA, Hanna WW, Yamada-Akiyama H, Ozias-Akins P (2011) Evolution of the apomixis transmitting chromosome in Pennisetum. BMC Evol Biol 11:289

Albertini E, Marconi G, Reale L, Barcaccia G, Porceddu A, Ferranti F, Falcinelli M (2005) SERK and APOSTART. Candidate genes 
for apomixis in Poa pratensis. Plant Physiol 138 (4):2185-2199. doi:10.1104/pp.105.062059

Aliyu OM, Schranz ME, Sharbel TF (2010) Quantitative variation for apomictic reproduction in the genus Boechera (Brassicaceae). Am J Bot 97(10):1719-1731. https://doi.org/10.3732/ajb.10001 88

Asker SEJL (1992) Apomixis in plants. CRC Press, London

Asker SE, Jerling L (1992) Apomixis in Plants. CRC Press, London

Barcaccia G, Arzenton F, Sharbel TF, Varotto S, Parrini P, Lucchin M (2006) Genetic diversity and reproductive biology in ecotypes of the facultative apomict Hypericum perforatum L. Heredity (Edinb) 96(4):322-334. https://doi.org/10.1038/sj.hdy.6800808

Barcaccia G, Albertini E (2013) Apomixis in plant reproduction: a novel perspective on an old dilemma. Plant Reprod 26(3):159179. https://doi.org/10.1007/s00497-013-0222-y

Barcaccia G, Varotto S, Meneghetti S, Albertini E, Porceddu A, Parrini P, Lucchin M (2001) Analysis of gene expression during flowering in apomeiotic mutants of Medicago spp.: cloning of ESTs and candidate genes for $2 \mathrm{n}$ eggs. Sex Plant Reprod 14 (4):233-238. doi:10.1007/s00497-001-0108-2

Barrett SCH (1988) The evolution, maintenance, and loss of selfincompatibiliy systems. Oxford University Press, New York, Plant reproductive ecology

Bicknell RA, Koltunow AM (2004) Understanding apomixis: recent advances and remaining conundrums. Plant Cell 16(Suppl):S228-245. https://doi.org/10.1105/tpc.017921

Boateng KA, Yang X, Dong F, Owen HA, Makaroff CA (2008) SWI1 is required for meiotic chromosome remodeling events. Mol Plant 1(4):620-633. https://doi.org/10.1093/mp/ssn030

Boldrini KR, Pagliarini MS, do Valle CB (2006) Cell fusion and cytomixis during microsporogenesis in Brachiaria humidicola (Poaceae). South African J Botany 72(3):478-481. https://doi. org/10.1016/j.sajb.2005.11.004

Bonilla JR, Quarin CL (1997) Diplosporous and aposporous apomixis in a pentaploid race of Paspalum minus. Plant Sci 127:97-104

Burgess MB, Cushman KR, Doucette ET, Talent N, Frye CT, Campbell CS (2014) Effects of apomixis and polyploidy on diversification and geographic distribution in Amelanchier (Rosaceae). Am J Bot 101(8):1375-1387. https://doi.org/10.3732/ajb.1400113

Chen X, Lai H-G, Sun Q, Liu J-P, Chen S-B, Zhu W-L (2018) Induction of apomixis by dimethyl sulfoxide (DMSO) and genetic identification of apomictic plants in cassava. Breed Sci. https:// doi.org/10.1270/jsbbs. 17089

Conner JA, Mookkan M, Huo H, Chae K, Ozias-Akins P (2015) A parthenogenesis gene of apomict origin elicits embryo formation from unfertilized eggs in a sexual plant. Proc Natl Acad Sci USA 112(36):11205-11210. https://doi.org/10.1073/pnas.1505856112

Dedong G, Chuanhong K, Liping L, Yong L (1999) Study of Apomixis in the Allotriploid Beet (VVC). Sci Agric Sinica 32(4):1-5

Dijk. PJv, Bakx-Schotman. JMT, (2004) Formation of unreduced megaspores (diplospory) in apomictic dandelions (Taraxacum officinale, s.l.) is controlled by a sex-specific dominant locus. Genetics 166:483-492

Dobes C, Milosevic A, Prohaska D, Scheffknecht S, Sharbel TF, Hulber K (2013) Reproductive differentiation into sexual and apomictic polyploid cytotypes in Potentilla puberula (Potentilleae, Rosaceae). Ann Bot 112(6):1159-1168. https://doi.org/10.1093/ aob/mct 167

Dobes C, Scheffknecht S, Fenko Y, Prohaska D, Sykora C, Hulber K (2018) Asymmetric reproductive interference: the consequences of cross-pollination on reproductive success in sexual-apomictic populations of Potentilla puberula (Rosaceae). Ecol Evol 8(1):365-381. https://doi.org/10.1002/ece3.3684
Dobeš C, Lückl A, Kausche L (2015) Parallel origins of apomixis in two diverged evolutionary lineages in tribe Potentilleae (Rosaceae). Bot J Linnean Soc 177:214-229

Dwivedi KK, Bhat SR, Bhat V, Bhat BV, Gupta MG (2007) Identification of a SCAR marker linked to apomixis in buffelgrass (Cenchrus ciliaris L.). Plant Science 172 (4):788-795. doi:10.1016/j.plantsci.2006.12.006

Dyer RJ, Savolainen V, Schneider H (2012) Apomixis and reticulate evolution in the Asplenium monanthes fern complex. Ann Bot 110:1515-1529. https://doi.org/10.1093/aob/mcs202

Ernst A (1918) Bastardierung als ursache der apogamie im pflanzenreich. Jena, Germany

Felitti SA, Seijo JG, Gonzalez AM, Podio M, Laspina NV, Siena L, Ortiz JP, Pessino SC (2011) Expression of lorelei-like genes in aposporous and sexual Paspalum notatum plants. Plant Mol Biol 77(4-5):337-354. https://doi.org/10.1007/s11103-011-9814-9

Ferreira LG, de Alencar Dusi DM, Irsigler AST, Gomes A, Mendes MA, Colombo L, de Campos Carneiro VT (2018) GID1 expression is associated with ovule development of sexual and apomictic plants. Plant Cell Rep 37(2):293-306. https://doi.org/10.1007/ s00299-017-2230-0

Folsom JJ, Begcy K, Hao X, Wang D, Walia H (2014) Rice fertilization-Independent Endosperm1 regulates seed size under heat stress by controlling early endosperm development. Plant Physiol 165(1):238-248. https://doi.org/10.1104/pp.113.232413

Galla G, Zenoni S, Avesani L, Altschmied L, Rizzo P, Sharbel TF, Barcaccia G (2017) Pistil transcriptome analysis to disclose genes and gene products related to aposporous apomixis in Hypericum perforatum L. Front Plant Sci 8:79. https://doi.org/10.3389/ fpls.2017.00079

Garcia-Aguilar M, Michaud C, Leblanc O, Grimanelli D (2010) Inactivation of a DNA methylation pathway in maize reproductive organs results in apomixis-like phenotypes. Plant Cell 22(10):3249-3267. https://doi.org/10.1105/tpc.109.072181

Grimanelli D, Garcı́a. M, Kaszas. E, Perotti. E, Leblanc. O, (2003) Heterochronic expression of sexual reproductive programs during apomictic development in Tripsacum. Genetics 165:1521-1531

Grusz AL, Windham MD, Pryer KM (2009) Deciphering the origins of apomictic polyploids in the Cheilanthes yavapensis complex (Pteridaceae). Am J Bot 96(9):1636-1645. https://doi. org/10.3732/ajb.0900019

Guerin J, Rossel JB, Robert S, Tsuchiya T, Koltunow A (2000) A deficiens homologue is down-regulated during apomictic initiation in ovules of Hieracium. Planta 76:914-920

Hand ML, Vit P, Krahulcova A, Johnson SD, Oelkers K, Siddons H, Chrtek J Jr, Fehrer J, Koltunow AM (2015) Evolution of apomixis loci in Pilosella and Hieracium (Asteraceae) inferred from the conservation of apomixis-linked markers in natural and experimental populations. Heredity (Edinb) 114(1):17-26. https ://doi.org/10.1038/hdy.2014.61

Hehenberger E, Kradolfer D, Kohler C (2012) Endosperm cellularization defines an important developmental transition for embryo development. Development 139(11):2031-2039. https://doi. org/10.1242/dev.077057

Hersh E, Grimm J, Whitton J (2016) Attack of the clones: reproductive interference between sexuals and asexuals in the crepis agamic complex. Ecol Evol 6(18):6473-6483. https://doi.org/10.1002/ ece 3.2353

Hofmann NR (2010) Apomixis and gene expression in Boechera. Plant Cell 22(3):539. https://doi.org/10.1105/tpc.110.220312

Hojsgaard D, Schegg E, Valls JFM, Martínez EJ, Quarin CL (2008) Sexuality, apomixis, ploidy levels, and genomic relationships among four Paspalum species of the subgenus Anachyris (Poaceae). Flora Morphol Distrib Functional Ecol Plants 203(7):535-547. https://doi.org/10.1016/j.flora.2007.09.005 
Hojsgaard D, Klatt S, Baier R, Carman JG, Horandl E (2014) Taxonomy and biogeography of apomixis in angiosperms and associated biodiversity characteristics. CRC Crit Rev Plant Sci 33(5):414-427. https://doi.org/10.1080/07352689.2014.898488

Hussain S, Curk F, Ollitrault P, Morillon R, Luro F (2011) Facultative apomixis and chromosome doubling are sources of heterogeneity in citrus rootstock trials: impact on clementine production and breeding selection. Sci Hortic 130(4):815-819. https://doi. org/10.1016/j.scienta.2011.09.009

Lovis JD (1977) Evolutionary patterns and processes in ferns. Adv Botanical Res 4:230-415

Khan YJ, Choudhary R, Tyagi H, Singh AK (2015) Apomixis: the molecular perspectives and its utilization in crop breeding. $\mathrm{J}$ AgriSearch 2(3):153-161

Kiyosu T, Ohad N, Yadegari R, Hannon M, Dinneny J, Wells D, Katz A, Margossian L, Harada JJ, Goldberg RB, Fischer RL (1999) Control of fertilization-independent endosperm development by the MEDEA polycomb gene in Arabidopsis. Proc Natl Acad Sci USA 96:4186-4191

Kliver S, Rayko M, Komissarov A, Bakin E, Zhernakova D, Prasad K, Rushworth C, Baskar R, Smetanin D, Schmutz J, Rokhsar DS, Mitchell-Olds T, Grossniklaus U, Brukhin V (2018) Assembly of the boechera retrofracta genome and evolutionary analysis of apomixis-associated genes. Genes (Basel) 9(4):185. https://doi. org $/ 10.3390 /$ genes 9040185

Koltunow AM (1993) Apomixis embryo sacs and embryos formed without meiosis or fertilization in ovules. Plant Cell 5:1425-1437

Koltunow AM (1993) Apomixis: embryo sacs and embryos formed without meiosis or fertilization in ovules. Plant Cell 5:1425-1437

Koltunow AM, Grossniklaus U (2003) Apomixis: a developmental perspective. Annu Rev Plant Biol 54:547-574. https://doi. org/10.1146/annurev.arplant.54.110901.160842

Kotani Y, Henderson ST, Suzuki G, Johnson SD, Okada T, Siddons H, Mukai Y, Koltunow AM (2014) The loss of apomeiosis (LOA) locus in Hieracium praealtum can function independently of the associated large-scale repetitive chromosomal structure. New Phytol 201(3):973-981. https://doi.org/10.1111/nph.12574

Laspina NV, Vega T, Seijo JG, Gonzalez AM, Martelotto LG, Stein J, Podio M, Ortiz JP, Echenique VC, Quarin CL, Pessino SC (2008) Gene expression analysis at the onset of aposporous apomixis in Paspalum notatum. Plant Mol Biol 67(6):615-628. https://doi. org/10.1007/s11103-008-9341-5

Li JJ, Hu ZM, Liu RY, Zhang J, Liu SL, Duan DL (2016) Phylogeographic surveys and apomictic genetic connectivity in the North Atlantic red seaweed Mastocarpus stellatus. Mol Phylogenet Evol 94(Pt B):463-472. https://doi.org/10.1016/j.ympev .2015.10.029

Litz RE, Knight RL, Gazit S (1982) Somatic embryos from culture ovules of polyembryonic Mangifera indica L. Plant Cell Rep 1:264-266

Liu DD, Dong QL, Fang MJ, Chen KQ, Hao YJ (2012a) Ectopic expression of an apple apomixis-related gene MhFIE induces co-suppression and results in abnormal vegetative and reproductive development in tomato. J Plant Physiol 169(18):1866-1873. https://doi.org/10.1016/j.jplph.2012.07.018

Liu DD, Dong QL, Sun C, Wang QL, You CX, Yao YX, Hao YJ (2012b) Functional characterization of an apple apomixisrelated MhFIE gene in reproduction development. Plant Sci 185186:105-111. https://doi.org/10.1016/j.plantsci.2011.09.004

Liu D-D, Fang M-J, Dong Q-L, Hu D-G, Zhou L-J, Sha G-L, Jiang Z-W, Liu Z, Hao Y-J (2014) Unreduced embryo sacs escape fertilization via a 'female-late-on-date' strategy to produce clonal seeds in apomictic crabapples. Sci Hortic 167:76-83. https://doi. org/10.1016/j.scienta.2013.12.035

Lo EY, Stefanovic S, Dickinson TA (2009) Population genetic structure of diploid sexual and polyploid apomictic hawthorns (Crataegus;
Rosaceae) in the Pacific Northwest. Mol Ecol 18(6):1145-1160. https://doi.org/10.1111/j.1365-294X.2009.04091.x

Lopes MA, Larkins BA (1993) Endosperm origin, development and function. Plant Cell 5:1383-1399

Lu C, Vasil IK (1981) Somatic embryogenesis and plant regeneration from leaf tissues of Panicum maximum Jacq. Theor Appl Genet 59:275-280

Mogie M (1992) The evolution of asexual reproduction in plants. Chapman and Hall, London

Maia FR, Varassin IG, Goldenberg R (2016) Apomixis does not affect visitation to flowers of Melastomataceae, but pollen sterility does. Plant Biol (Stuttg) 18(1):132-138. https://doi.org/10.1111/ plb. 12364

Mau M, Corral JM, Vogel H, Melzer M, Fuchs J, Kuhlmann M, de Storme N, Geelen D, Sharbel TF (2013) The conserved chimeric transcript UPGRADE2 is associated with unreduced pollen formation and is exclusively found in apomictic Boechera species. Plant Physiol 163(4):1640-1659. https://doi.org/10.1104/ pp.113.222448

Mendes-Rodrigues C, Oliveira PE (2012) Polyembryony in Melastomataceae from Brazilian Cerrado: multiple embryos in a small world. Plant Biol (Stuttg) 14(5):845-853. https://doi.org/10.111 1/j.1438-8677.2011.00551.x

Mieulet D, Jolivet S, Rivard M, Cromer L, Vernet A, Mayonove P, Pereira L, Droc G, Courtois B, Guiderdoni E, Mercier R (2016) Turning rice meiosis into mitosis. Cell Res 26(11):1242-1254. https://doi.org/10.1038/cr.2016.117

Nakano M, Shimada T, Endo T, Fujii H, Nesumi H, Kita M, Ebina M, Shimizu T, Omura M (2012) Characterization of genomic sequence showing strong association with polyembryony among diverse Citrus species and cultivars, and its synteny with Vitis and Populus. Plant Sci 183:131-142. https://doi. org/10.1016/j.plantsci.2011.08.002

Nassar NMA, Collevati R (2008) Embryonic, meiotic and molecular analysis of apomictic. Gene Conserve 29:475-497

Naumova TN, van der Laak J, Osadtchiy J, Matzk F, Kravtchenko A, Bergervoet J, Ramulu KS, Boutilier K (2001) Reproductive development in apomictic populations of Arabis holboellii (Brassicaceae). Sex Plant Reprod 14(4):195-200. https://doi. org/10.1007/s00497-001-0118-0

Niemann J, Wojciechowski A, Janowicz J (2012) Identification of apomixis in the Kentucky bluegrass (Poa pratensis L.) using auxin test. Acta Societatis Botanicorum Poloniae 81 (3):217221. doi:10.5586/asbp. 2012.020

Nogler G (1984) Gametophytic apomixis. Embryology of Angiosperms, Springer, Berlin

Nonomura KI (2003) The MSP1 gene is necessary to restrict the number of cells entering into male and female sporogenesis and to initiate anther wall formation in rice. The Plant Cell Online 15(8):1728-1739. https://doi.org/10.1105/tpc.012401

Novak S, Mack RN (1995) Allozyme diversity in the apomictic vine Bryonia alba (cucurbitaceae): potential consequences of multiple introductions. Am J Bot 82(9):1153-1162

Noyes RD, Rieseberg LH (2000) Two independent loci control agamospermy (Apomixis) in the triploid flowering plant Erigeron annuus. Genetics 155:379-390

Ogawa D, Johnson SD, Henderson ST, Koltunow AMG (2013) Genetic separation of autonomous endosperm formation (AutE) from the two other components of apomixis in Hieracium. Plant Reprod 26:113-123. https://doi.org/10.1007/s0049 7-013-0214-y)

Ogawa T, Ohki K, Kamiya M (2015) High heterozygosity and phenotypic variation of zoids in apomictic Ulva prolifera (Ulvophyceae) from brackish environments. Aquat Bot 120:185-192. https ://doi.org/10.1016/j.aquabot.2014.05.015 
Okada T, Hu Y, Tucker MR, Taylor JM, Johnson SD, Spriggs A, Tsuchiya T, Oelkers K, Rodrigues JC, Koltunow AM (2013) Enlarging cells initiating apomixis in Hieracium praealtum transition to an embryo sac program prior to entering mitosis. Plant Physiol 163(1):216-231. https://doi.org/10.1104/pp.113.219485

Olmedo-Monfil V, Durán-Figueroa N, Arteaga-Vázquez M, DemesaArévalo E, Autran D, Grimanelli D, Slotkin RK, Martienssen RA, Vielle-Calzada J-P (2010) Control of female gamete formation by a small RNA pathway in Arabidopsis. Nature 464(7288):628-632. https://doi.org/10.1038/nature08828

Park CHKM (2003) Apomixis in the interspecific triploid hybrid fern Cornopteris christenseniana (Woodsiaceae). J Plant Res 116:93-103

Pichot CMM, Raddi S, Raddi P (2001) Surrogate mother for endangered Cupressus. Nature 133:39

Podio M, Felitti SA, Siena LA, Delgado L, Mancini M, Seijo JG, González AM, Pessino SC, Ortiz JPA (2014) Characterization and expression analysis of somatic embryogenesis receptor kinase (SERK) genes in sexual and apomictic Paspalum notatum. Plant Mol Biol 84:479-495. https://doi.org/10.1007/ s11103-013-0146-9)

Podio M, Caceres ME, Samoluk SS, Seijo JG, Pessino SC, Ortiz JP, Pupilli F (2014) A methylation status analysis of the apomixisspecific region in Paspalum spp. suggests an epigenetic control of parthenogenesis. J Exp Bot 65 (22):6411-6424. doi:10.1093/ jxb/eru354

Pupilli F, Barcaccia G (2012) Cloning plants by seeds: inheritance models and candidate genes to increase fundamental knowledge for engineering apomixis in sexual crops. J Biotechnol 159(4):291-311. https://doi.org/10.1016/j.jbiotec.2011.08.028

Radhakrishna A, Dwivedi KK, Srivastava MK, Roy AK, Malaviya DR, Kaushal P (2018) Transcriptomic data of pre-meiotic stage of floret development in apomictic and sexual types of guinea grass (Panicum maximum Jacq.). Data in Brief 18:590-593. https:// doi.org/10.1016/j.dib.2018.03.001

Ravi M, Marimuthu MP, Siddiqi I (2008) Gamete formation without meiosis in Arabidopsis. Nature 451(7182):1121-1124. https:// doi.org/10.1038/nature06557

Richards AJ (1986) Plant breeding systems. Allen \& Unwin, London

Rojek J, Pawełko Ł, Kapusta M, Naczk A, Bohdanowicz J (2015) Exogenous steroid hormones stimulate full development of autonomous endosperm in Arabidopsis thaliana. Acta Soc Bot Pol 84(2):287-301. https://doi.org/10.5586/asbp.2015.022

Sahu PP, Gupta S, Malaviya DR, Roy AK, Kaushal P, Prasad M (2012) Transcriptome analysis of differentially expressed genes during embryo sac development in apomeiotic non-parthenogenetic interspecific hybrid of Pennisetum glaucum. Mol Biotechnol 51:262-271. https://doi.org/10.1007/s12033-011-9464-9)

Sampaio DS, Júnior NSB, Oliveira PE (2013) Sporophytic apomixis in polyploid Anemopaegma species (Bignoniaceae) from central Brazil. Bot J Linn Soc 173:77-91

Schmidt A, Schmid MW, Klostermeier UC, Qi W, Guthorl D, Sailer C, Waller M, Rosenstiel P, Grossniklaus U (2014) Apomictic and sexual germline development differ with respect to cell cycle, transcriptional, hormonal and epigenetic regulation. PLoS Genet 10(7):e1004476. https://doi.org/10.1371/journal.pgen.1004476

Schwartz YB, Pirrotta V (2008) Polycomb complexes and epigenetic states. Curr Opin Cell Biol 20(3):266-273. https://doi. org/10.1016/j.ceb.2008.03.002

Selva JP, Siena L, Rodrigo JM, Garbus I, Zappacosta D, Romero JR, Ortiz JPA, Pessino SC, Leblanc O, Echenique V (2017) Temporal and spatial expression of genes involved in DNA methylation during reproductive development of sexual and apomictic Eragrostis curvula. Sci Rep 7(1):15092. https://doi.org/10.1038/ s41598-017-14898-5
Selva J-P, Pessino SC, Meier MS, Echenique VC, (2012) Identification of candidate genes related to polyploidy and/or apomixis in Eragrostis curvula. Am J Plant Sci 03(03):403-416. https://doi. org/10.4236/ajps.2012.33049

Sharbel TF, Voigt ML, Corral JM, Thiel T, Varshney A, Kumlehn J, Vogel H, Rotter B (2009) Molecular signatures of apomictic and sexual ovules in the Boechera holboellii complex. Plant $\mathrm{J}$ 58(5):870-882. https://doi.org/10.1111/j.1365-313X.2009.03826 $\mathrm{X}$

Sharma R, Geeta R, Bhat V (2014) Asynchronous male/female gametophyte development in facultative apomictic plants of Cenchrus ciliaris (Poaceae). South African J Bot 91:19-31. https://doi. org/10.1016/j.sajb.2013.10.012

Siena LA, Ortiz JPA, Leblanc O, Pessino. aS, (2014) PnTgs1-like expression during reproductive development supports a role for RNA methyltransferases in the aposporous pathway. BMC Plant Biol 14:297

Siena LA, Ortiz JP, Calderini O, Paolocci F, Caceres ME, Kaushal P, Grisan S, Pessino SC, Pupilli F (2016) An apomixis-linked ORC3-like pseudogene is associated with silencing of its functional homolog in apomictic Paspalum simplex. J Exp Bot 67(6):1965-1978. https://doi.org/10.1093/jxb/erw018

Singh M, Goel S, Meeley RB, Dantec C, Parrinello H, Michaud C, Leblanc O, Grimanelli D (2011) Production of viable gametes without meiosis in maize deficient for an Argonaute protein. Plant Cell 23(2):443-458. https://doi.org/10.1105/tpc.110.079020

Souza-Pérez M, Speroni G (2017) New apomictic pathway in Myrtaceae inferred from Psidium cattleyanum female gametophyte ontogeny. Flora 234:34-40. https://doi.org/10.1016/j.flora .2017.06.010

Spielman M, Vinkenoog R, Scott RJ (2003) Genetic mechanisms of apomixis. Philos Trans R Soc Lond B Biol Sci 358(1434):10951103. https://doi.org/10.1098/rstb.2003.1298

Szkutnik T (2010) Apomixis in the Sugar Beet Reproduction System. Acta Bio Cracov Ser Bot 52(1):87-96. https://doi.org/10.2478/ v10182-010-0011-y

Walker TG, (1966) A cytotaxonomic survey of the pteridophytes of Jamaica. Trans R Soc Edinb 66:169-237

Tucker MR (2003) Sexual and apomictic reproduction in Hieracium subgenus Pilosella are closely interrelated developmental pathways. Plant Cell Online 15(7):1524-1537. https://doi. org/10.1105/tpc.011742

Vielle-Calzada J-P, Nuccio ML, Budiman MA, Thomas TL, Burson BL, Hussey MA, Wing RA (1996) Comparative gene expression in sexual and apomictic ovaries of Pennisetum ciliare (L.) Link. Plant Mol Biol 32:1085-1092

Wang X, Xu Y, Zhang S, Cao L, Huang Y, Cheng J, Wu G, Tian S, Chen C, Liu Y, Yu H, Yang X, Lan H, Wang N, Wang L, Xu J, Jiang X, Xie Z, Tan M, Larkin RM, Chen LL, Ma BG, Ruan Y, Deng X, Xu Q (2017) Genomic analyses of primitive, wild and cultivated citrus provide insights into asexual reproduction. Nat Genet 49(5):765-772. https://doi.org/10.1038/ng.3839

Whitton J, Dlugosch KM, Sears CJ (2008) Molecular and morphological evidence for and against gene flow in sympatric apomicts of the North American Crepis agamic complex (Asteraceae) this paper is one of a selection of papers published in the special issue on systematics research. Botany 86(8):877-885. doi:10.1139/ b08-071

Windham MD (1993) New taxa and nomenclatural changes in the North American fern flora. Contrib Univ Mich Herb 19:31-61

Worthington M, Heffelfinger C, Bernal D, Quintero C, Zapata YP, Perez JG, De Vega J, Miles J, Dellaporta S, Tohme J (2016) A parthenogenesis gene candidate and evidence for segmental allopolyploidy in apomictic Brachiaria decumbens. Genetics 203(3):1117-1132. https://doi.org/10.1534/genetics.116.190314 
Zhang B, Wang ZJ, Jin SH, Xia GH, Huang YJ, Huang JQ (2012) A pattern of unique embryogenesis occurring via apomixis in Carya cathayensis. Biol Plant 56(4):620-627. https://doi.org/10.1007/ s10535-012-0256-2

Zhao L, He J, Cai H, Lin H, Li Y, Liu R, Yang Z, Qin Y (2014) Comparative expression profiling reveals gene functions in female meiosis and gametophyte development in Arabidopsis. Plant $\mathbf{J}$ 80(4):615-628. https://doi.org/10.1111/tpj.12657
Publisher's Note Springer Nature remains neutral with regard to jurisdictional claims in published maps and institutional affiliations. 